\title{
THE FUTURE OF ACADEMIC HAEMATOLOGY
}

Deborah Hay ${ }^{1}$, Christian S.R. Hatton ${ }^{1}$ and David J. Weatherall ${ }^{2}$

1 Department of Haematology, Oxford University Hospitals NHS Foundation Trust, Oxford

2 MRC Weatherall Institute of Molecular Medicine, University of Oxford

Correspondence to: Professor Sir David Weatherall FRS

MRC Weatherall Institute of Molecular Medicine John Radcliffe Hospital

Headington, Oxford, OX3 9DS, UK

Email: liz.rose@imm.ox.ac.uk 


\section{Summary}

Recent advances in the basic medial sciences, particularly cell biology and genomics, have great promise for the future development of all aspects of haematological practice. They will also impinge on the hitherto neglected fields of haematology including haematology involving the care of the rapidly increasing number of elderly patients and the complex problems of haematological practice in the developing countries. To obtain the maximum benefit from these new developments it will be necessary to review the patterns of training of haematologists of the future at every level. In short, it will be important to try to design and develop various career pathways for training haematologists including those who wish to work full time in basic research, combine research with clinical practice, or commit all their time to clinical work and teaching.

\section{Keywords}

Genomics, Next-generation sequencing; Neglected disease, Training

The Concise Oxford Dictionary defines the usage of the word 'academic' in several ways including "relating to education" or "of no practical relevance". The former definition is of course relevant to all aspects of medical education at every level, while the latter is consistent with recent attacks on the basic biological sciences which claim that they have played little or no role in the improvement of health care (Chalmers et al, 2014). Yet an analysis of the history of the development of haematology over the last four hundred years (Wintrobe, 1980) suggests that many of its clinical successes were based on curiosity-driven basic research. Some examples are shown in Table 1.

More recent criticism of the clinical value of basic medical research also followed the announcement of the successful completion of the human genome project in 2001- 
2003. It was claimed that the results of this remarkable achievement would, within the next twenty years, define the causes and approaches to the management of many common diseases and lead to an era of personalised or stratified medicine. However, it soon became apparent that because of the extreme complexity of the structure and regulation of the human genome these predictions were premature. However, during recent years there have been remarkable technical advances in genomics and in the related fields of proteomics, metabolomics, phenomics and pharmacogenomics. These advances have been reviewed by the Royal Society (2005, 2015) and the Academy of Medical Sciences (2013). It is now clear that these branches of the basic medical sciences will play a major translational role in the diagnosis and management of many diseases in the future and will undoubtedly provide a basis for the further evolution of haematological practice.

In this review we outline some of the recent advances in the basic medical sciences related to haematology, discuss the future importance of some of the neglected areas of haematology and attempt to define the educational requirements for the future amalgamation of the basic and clinical aspects of haematological practice.

\section{Advances in the basic biological sciences related to future haematological practice}

Over recent years the development of the clinical applications of next-generation sequencing of both DNA and RNA have become applicable to a wide range of clinical disorders (Park et al, 2013, Van Keuren-Jensen et al, 2014). These advances, together with a better understanding of the cell biology of haemopoiesis (Brown \& Sanchez-Garcia, 2016) are likely to play a major role in the practice of all aspects of haematology in the future. The two examples which follow provide strong support for this prediction.

The technologies of cytogenetics and molecular genetics are already applied widely for the classification, diagnosis, prognosis and management of the leukaemias and 
other malignant diseases of the blood (Provan \& Gribben, 2010). The recent applications of next-generation sequencing to genome-wide association studies (GWAS), exome sequencing and transcriptome (RNA) analysis are showing increasing clinical potential. For example the Cancer Genome Atlas (International Cancer Genome Consortium et al, 2010) and the International Cancer Genomics Consortium (Ledford, 2010) have identified a number of consistent point mutations and translocations with therapeutic potential. Another example is the Pediatric Cancer Genome Project (Downing et al, 2012). Genome-wide association studies (GWAS) were carried out on 600 paediatric tumours and 600 non-malignant germline samples with the expectation that the information gained will have broad clinical application. As well as defining potential therapeutic targets, detailed sequencing studies have also provided insights that have revised our previously accepted paradigms of the initiation and natural history of haematological malignancies. Studies on serial samples from patients allow us to define 'driver' versus 'passenger' mutations, and highlight the complexity of clonal evolution during tumour growth and treatment. The therapeutic potential of genetic data obtained by these approaches and its relationship to the development of clinical trials is discussed by Simon \& Roychowdhury (2013) and some examples relating to haematological malignancies are shown in Table 2.

The second example of the value of next-generation sequencing technology is its clinical potential for the more effective prevention and management of single gene (Mendelian) disorders. The inherited disorders of haemoglobin are by far the commonest single-gene disorders, particularly sickle cell disease and the different forms of thalassaemia. It is estimated that there are 300,000 to 400,000 births per year, $80 \%$ of which occur in low or medium income countries (Christianson et al, 2006). The current approaches to screening and invasive prenatal diagnosis are reviewed by Cao \& Kan (2013). There is now promising progress towards the development of non-invasive prenatal diagnosis by applying next-generation 
sequencing of the fetal genome present in maternal plasma (Lo \& Chiu, 2010). A major characteristic of the haemoglobinopathies is their remarkable phenotypic diversity. A better understanding of the genetic basis for this variability is vital for the early assessment of their prognosis and future management. The role of recent GWAS studies of this problem, reviewed by Lettre (2013), emphasise their value in identifying genes which modify the level of fetal haemoglobin in sickle cell anaemia and beta thalassaemia, work which is leading to the possibility of therapeutic approaches to increase its levels to produce a milder phenotype (Masuda et al, 2016). It seems likely therefore that the application of this new technology will also be effective in identifying the primary, secondary and tertiary modifiers that underlie the complex phenotypic variability of these diseases in the future (Weatherall, 2001).

Research progress towards gene therapy for the haemoglobin disorders using retroviral vectors and related approaches is reviewed by Nienhuis \& Persons (2013). Although progress is slow successes have been reported (Cavazzana-Calvo et al, 2010) and with the use of new gene-editing techniques further progress in the near future seems very likely (Orkin \& Reilly, 2016). It is also likely that these advances in the haemoglobinopathies will have relevance to many other monogenic haematological diseases.

From these brief reviews it is clear that patient care in the future will include the application of increasingly complex genetic information, a prediction which has important implications for the training of haematologists.

\section{Neglected aspects of haematology requiring urgent action}

Every aspect of clinical practice requires vision and future planning and haematology is no exception. The sections which follow offer two examples of important future developments in haematological practice. 
The haematology of aged populations. The rapid increase in the aged population is putting a heavy strain on the provision of health care in every advanced country. A recent review of haematology in the aged (Ershler et al, 2016), against the background of our limited knowledge about the biology of ageing, describes the steady decline in bone marrow cellularity and in thymic mass with age. Surprisingly, various transplant experiments have shown that the activity of haemopoietic stem cells does not decline with age. There is as yet an unexplained high frequency of mild anaemia, as defined by the World Health Organization (WHO) criteria, in aged populations. Studies of the regulation of red cell production by erythropoietin in ageing and related hypoxic responses have so far given inconsistent results. For reasons that are also not clear there appears to be an age-related activation of coagulation and fibrinolytic pathways which increase the risk of thrombus formation and a variety of other conditions. Another neglected issue in most aspects of medical practice is the pharmacology of ageing. Very little is known about the effect of ageing on drug metabolism and drug doses are rarely modified from those given to younger patients. It is clear that in the future the haematology of ageing will require increasing interaction between both basic researchers and clinical practice in the field of haematology.

Global haematology. A recent edition of Hematology/Oncology Clinics of North America, edited by Roberts \& Weatherall (2016), includes a series of papers relating to haematological practice in the developing countries, particularly those of South and Southeast Asia and sub-Saharan Africa. The articles include a description of the various types of haematological disease in these countries together with the current state of their diagnosis and management, the problems of diagnosis against a background of multiple pathology, the difficulties of establishing blood transfusion programmes, the lack of basic analytical equipment in many laboratories, and many other related issues. It also includes an account of some of the difficulties 
encountered by those attempting to help the developing countries to improve haematological practice.

In its publication Genomics and World Health (Weatherall et al, 2002) the WHO encouraged the development of what are sometimes called North/South partnerships, that is partnerships between rich and poor countries for the development of improved clinical care in the latter. In the case of the inherited disorders of haemoglobin and related genetic diseases this approach was approved later at the $59^{\text {th }}$ World Health Assembly. So far the WHO have provided little support for these projects although partnerships of this kind have been established with the help of several haematological departments in the UK and elsewhere. They require much more than simply training young doctors from the developing countries. They involve constant travel in both directions, combining capacity building with, at least in some cases, research and developing good relationships with the governments of the poor countries (Weatherall, 2010). Funding for these partnerships has been difficult to obtain. It is vital that this message is conveyed to the WHO, other international agencies and charities and funding bodies. It will also require a major effort in persuading universities and postgraduate teaching bodies that their clinical training should focus more time on international health.

\section{Training for the Future in Haematological Practice}

\section{Clinical training}

The opportunities for the future practice of haematology are great, but is it clear that if we are to make the most of advances in basic haematological science, then clinicians will need to be fluent in the language of their scientific colleagues. Routine clinical practice now requires an appreciation of the use of quantitative polymerase chain reaction for the detection of minimal residual disease and next-generation sequencing for the massively parallel detection of disease-causing and diseaseassociated mutations in haematological malignancies. An understanding of the flaws 
and limitations of these technologies is essential for scientifically and clinically literate patient care, even before we consider the importance of clinical and scientific cooperation on the major unanswered questions in haematology.

At present, academic and scientific training for haematologists remains optional, undertaken as part of 'out of programme' (OOP) attachments for research and experience. These are typically organized by haematologists in training themselves, and funded by external research agencies. While such attachments, usually leading to award of a higher degree, are popular with those who have academic ambitions, there is no obligation for haematologists who wish to pursue careers wholly within the clinical sector to engage with these opportunities. Since the most recent higher specialist training curriculum for haematologists (amended 2012; http://www.gmc-uk .org/Haematology 3 Jul 07 v.Curr 0017.pdf 30541824.pdf) makes little reference to molecular genetics, and no reference at all to genomics, it is quite possible for haematologists to emerge from their clinical training with a severely restricted appreciation of the significance of advances in basic science. Where that scientific training is delivered, it is outwith the national training programme, with no recognised curriculum, standards, or assessment. Whether the specialist curriculum reflects our understanding of current concepts of haematological disease is itself debatable, as will be evident from the summary presented in Table 3; taken from the table of contents to the current specialist curriculum, this outline does not map readily to a modern view of haemopoiesis or pathophysiology.

The demands on the time and energies of the training haematologist are not to be underestimated. During a five year higher specialist training programme, registrars are expected to pass both parts of the FRCPath examination, requiring competence across a breadth of clinical and laboratory practice that must be exceptional among specialties. They are expected to gain sufficient experience in areas as diverse as haemophilia and allogeneic transplantation, hospital transfusion practice and lymphoma, paediatric bone marrow failure syndromes and laboratory management. 
The rate of expansion of patient-facing ward and clinical work in the fields of haematological malignancies means that there has already been significant impingement on laboratory training opportunities available to many haematologists. Adding a further substantial expectation in the understanding of basic science risks stretching laboratory training time ever more thinly across an expanding curriculum.

The additional changes indicated by the Joint Royal Colleges' Shape of Training Review (www.shapeoftraining.co.uk 2014) with its amalgamation of core medical and specialty training into a 4-6 year 'broad based specialty training' programme' (Figure 1), have been the cause of some consternation among haematologists. Effectively shortening specialty training by another year and introducing an additional emphasis on acute medical management, the Shape of Training review has been seen by some as exacerbating still further haematology's already too-thinly spread curriculum.

Yet this may offer the best solution to haematology's expanding clinical reach and to the necessity of expanding basic scientific training within haematology. The option of 'credentialing' following the award of a certificate of special training (CST) suggested by the Shape of Training review may represent an opportunity for haematologists to bring the kind of scientific advances described in the opening paragraphs of this article into the mainstream of clinical practice.

Currently all training haematologists, irrespective of their subspecialty interest and experience, are required to complete a five year clinical training programme which allows them to practise in any field of haematology, be it within a district general hospital, haematological malignancies diagnostics laboratory, specialist haemophilia unit or transplant centre. Few would argue that the current training programme equips registrars with the skills to fulfill many of these roles. By introducing formalized post-CST credentialing after an abbreviated generalist training (such as that proposed by the Shape of Training review), we would be able to drop the 
pretence that FRCPath part II constitutes a ticket for competent practice in all of these areas of haematology. Moving specialist haematology to the post-CST phase (perhaps with post-CST diploma qualifications) would allow a modernization of the curriculum, facilitate earlier specialization and make space during generic training to ensure that all clinicians gain some exposure to the advances in clinical science described above. Post-CST subspecialist training might focus on molecular genetic and genomic haematology, international health, clinical trials, and a host of other key areas which are currently under-represented in haematology training. Smaller, more focused subspeciality training curricula would be more responsive to scientific and clinical advances, more flexible in their development.

\section{Academic training}

Out of programme placements for research are typically limited to three years' duration. For registrars who are part of the National Institute of Health Research integrated academic training path as academic clinical fellows (ACFs), protected time is made available prior to a doctoral research project for the development of a research interest. This enables young haematologists with little or no research experience to accrue preliminary data, and to access good scientific and clinical mentorship prior to applying for clinical training fellowships in research. While $25 \%$ of their training time in their first three years as a specialist registrar is spent in research, the timing and distribution of this time (whether in three month instalments, or in a single nine month block) is typically determined by the clinical requirements of the training rotation in which they work. In some cases, the protected academic time of ACFs is backfilled by registrars in non-academic training posts, with inevitable impact on their training.

By contrast, the majority of haematology registrars who are appointed to "nonacademic" national training numbers, academic training may be negligible or even absent. Approval for time out of programme is not guaranteed, and the opportunity to 
step out of highly regulated training rotations may be determined by wholly nonacademic factors (e.g. staffing shortages or service expansion).

Following research, registrars currently return to a clinical training programme to be exposed to the full range of haematological practice again. For many who have chosen a subspecialty area of interest, and who are aiming for academic careers, time spent working in clinical areas quite distinct from their future clinical practice feels like time wasted - especially for those who have already completed their FRCPath exams. This is especially galling for those who are unable to undertake further research. Currently, the only means by which registrars with either designated academic or standard training posts may take time for postdoctoral research is through the small number of highly competitive NIHR academic clinical lectureships (ACLs). These typically supernumerary posts permit up to two years of protected time for research, and are designed to allow young doctors to gain momentum in their application for intermediate clinical fellowships. Without an ACL, haematologists are obliged to wait for the end of their training attachments (two years or possibly more) before being able to continue with their careers plan.

We appreciate the need for workforce planning both at registrar and consultant level;

but the current system for training young haematologists, whether academic or clinical lacks the flexibility and responsiveness essential for this most progressive of specialties. It is not yet clear how the NIHR integrated academic training pathway will incorporate the changes required by The Shape of Training review, but we believe this is an opportunity to become more ambitious for the education of a new generation of haematologists.

\section{Conclusion}

It seems very clear that the recent developments in the basic biological sciences are going to play a major role in the future development of haematological practice including some areas which have hitherto been rather neglected. These advances 
also have relevance to the extremely complex haematological problems of the developing countries, particularly those in the tropical belt. To achieve maximum improvements in haematological practice based on these new developments there will need to be a careful review of the current training programmes for haematologists at every level and an encouragement for medical student training towards a more global approach.

\section{Acknowledgements}

We thank Dr. Roychowdhury for permission to use extracts from a table in Simon \& Roychowdhury (2013) and Liz Rose for her help in preparing this paper. DH, CSRH and DJW contributed equally to writing the paper.

\section{Disclosure of Interest}

No conflicts of interest 


\section{Captions for Tables}

Table 1: Some examples of basic curiosity-driven science over the centuries which had a major impact on clinical practice in haematology (Wintrobe, 1980).

Table 2: Genomic alterations as putative predictive biomarkers for different forms of haematological malignancy (data extracted from Simon \& Rowchowdhury (2013) with permission).

Table 3: Higher specialist training curriculum in haematology - failing to represent our current understanding of haematological disease. 


\section{Captions for Figure}

Figure 1: Overview of the Shape of Training review. An abbreviated specialist training programme could allow a modernisation of general haematology training and earlier subspeciality focus. 


\section{References}

Academy of Medical Sciences (2013) Realising the potential of stratified medicine. http://www.acmedsci.ac.uk/p99puid280.html.

Brown, G. \& Sanchez-Garcia, I. (2016) Diversity, Versatility and Leukaemia. New York, Nova Science.

Cao, A. \& Kan, Y.W. (2013) The prevention of thalassemia. Cold Spring Harbor perspectives in medicine: doi: 10.1101/cshperspect.a011775.

Cavazzana-Calvo, M., Payen, E., Negre, O., Wang, G., Hehir, K., Fusil, F., Down, J., Denaro, M., Brady, T., Westerman, K., Cavallesco, R., Gillet-Legrand, B., Caccavelli, L., Sgarra, R., Maouche-Chretien, L., Bernaudin, F., Girot, R., Dorazio, R., Mulder, G.J., Polack, A., Bank, A., Soulier, J., Larghero, J., Kabbara, N., Dalle, B., Gourmel, B., Socie, G., Chretien, S., Cartier, N., Aubourg, P., Fischer, A., Cornetta, K., Galacteros, F., Beuzard, Y., Gluckman, E., Bushman, F., Hacein-Bey-Abina, S. \& Leboulch, P. (2010) Transfusion independence and HMGA2 activation after gene therapy of human betathalassaemia. Nature, 467: 318-322.

Chalmers, I., Bracken, M.B., Djulbegovic, B., Garattini, S., Grant, J., Gulmezoglu, A.M., Howells, D.W., Ioannidis, J.P. \& Oliver, S. (2014) How to increase value and reduce waste when research priorities are set. Lancet, 383: 156-165.

Christianson, A., Howson, C.P. \& Modell, B. (2006) March of Dimes Global Report on Birth Defects. New York, March of Dimes Birth Defects Foundation.

Downing, J.R., Wilson, R.K., Zhang, J., Mardis, E.R., Pui, C.H., Ding, L., Ley, T.J. \& Evans, W.E. (2012) The Pediatric Cancer Genome Project. Nat Genet, 44: 619622.

Ershler, W.B., Artz, A.S. \& Kanapuru, B. (2016) Hematology in Older Persons. Williams Hematology. $9^{\text {th }}$ Edn. Editors: Kavshansky, K., Lichtman, M.A., Prchal, J.T., Levi, M.M., Press, O.W., Burns, L.J. \& Caligiuri, M.A. New York, McGraw Hill Education. 
International Cancer Genome Consortium, Hudson, T.J., Anderson, W., Artez, A., Barker, A.D., Bell, C., Bernabe, R.R., Bhan, M.K., Calvo, F., Eerola, I., Gerhard, D.S., Guttmacher, A., Guyer, M., Hemsley, F.M., Jennings, J.L., Kerr, D., Klatt, P., Kolar, P., Kusada, J., Lane, D.P., Laplace, F., Youyong, L., Nettekoven, G., Ozenberger, B., Peterson, J., Rao, T.S., Remacle, J., Schafer, A.J., Shibata, T., Stratton, M.R., Vockley, J.G., Watanabe, K., Yang, H., Yuen, M.M., Knoppers, B.M., Bobrow, M., Cambon-Thomsen, A., Dressler, L.G., Dyke, S.O., Joly, Y., Kato, K., Kennedy, K.L., Nicolas, P., Parker, M.J., Rial-Sebbag, E., RomeoCasabona, C.M., Shaw, K.M., Wallace, S., Wiesner, G.L., Zeps, N., Lichter, P., Biankin, A.V., Chabannon, C., Chin, L., Clement, B., de Alava, E., Degos, F., Ferguson, M.L., Geary, P., Hayes, D.N., Hudson, T.J., Johns, A.L., Kasprzyk, A., Nakagawa, H., Penny, R., Piris, M.A., Sarin, R., Scarpa, A., Shibata, T., van de Vijver, M., Futreal, P.A., Aburatani, H., Bayes, M., Botwell, D.D., Campbell, P.J., Estivill, X., Gerhard, D.S., Grimmond, S.M., Gut, I., Hirst, M., Lopez-Otin, C., Majumder, P., Marra, M., McPherson, J.D., Nakagawa, H., Ning, Z., Puente, X.S., Ruan, Y., Shibata, T., Stratton, M.R., Stunnenberg, H.G., Swerdlow, H., Velculescu, V.E., Wilson, R.K., Xue, H.H., Yang, L., Spellman, P.T., Bader, G.D., Boutros, P.C., Campbell, P.J., Flicek, P., Getz, G., Guigo, R., Guo, G., Haussler, D., Heath, S., Hubbard, T.J., Jiang, T., Jones, S.M., Li, Q., Lopez-Bigas, N., Luo, R., Muthuswamy, L., Ouellette, B.F., Pearson, J.V., Puente, X.S., Quesada, V., Raphael, B.J., Sander, C., Shibata, T., Speed, T.P., Stein, L.D., Stuart, J.M., Teague, J.W., Totoki, Y., Tsunoda, T., Valencia, A., Wheeler, D.A., Wu, H., Zhao, S., Zhou, G., Stein, L.D., Guigo, R., Hubbard, T.J., Joly, Y., Jones, S.M., Kasprzyk, A., Lathrop, M., Lopez-Bigas, N., Ouellette, B.F., Spellman, P.T., Teague, J.W., Thomas, G., Valencia, A., Yoshida, T., Kennedy, K.L., Axton, M., Dyke, S.O., Futreal, P.A., Gerhard, D.S., Gunter, C., Guyer, M., Hudson, T.J., McPherson, J.D., Miller, L.J., Ozenberger, B., Shaw, K.M., Kasprzyk, A., Stein, L.D., Zhang, J., Haider, S.A., Wang, J., Yung, C.K., Cros, A., Liang, Y., Gnaneshan, S., Guberman, J., Hsu, J., Bobrow, M., Chalmers, D.R., Hasel, 
K.W., Joly, Y., Kaan, T.S., Kennedy, K.L., Knoppers, B.M., Lowrance, W.W., Masui, T., Nicolas, P., Rial-Sebbag, E., Rodriguez, L.L., Vergely, C., Yoshida, T., Grimmond, S.M., Biankin, A.V., Bowtell, D.D., Cloonan, N., deFazio, A., Eshleman, J.R., Etemadmoghadam, D., Gardiner, B.B., Kench, J.G., Scarpa, A., Sutherland, R.L., Tempero, M.A., Waddell, N.J., Wilson, P.J., McPherson, J.D., Gallinger, S., Tsao, M.S., Shaw, P.A., Petersen, G.M., Mukhopadhyay, D., Chin, L., DePinho, R.A., Thayer, S., Muthuswamy, L., Shazand, K., Beck, T., Sam, M., Timms, L., Ballin, V., Lu, Y., Ji, J., Zhang, X., Chen, F., Hu, X., Zhou, G., Yang, Q., Tian, G., Zhang, L., Xing, X., Li, X., Zhu, Z., Yu, Y., Yu, J., Yang, H., Lathrop, M., Tost, J., Brennan, P., Holcatova, I., Zaridze, D., Brazma, A., Egevard, L., Prokhortchouk, E., Banks, R.E., Uhlen, M., Cambon-Thomsen, A., Viksna, J., Ponten, F., Skryabin, K., Stratton, M.R., Futreal, P.A., Birney, E., Borg, A., Borresen-Dale, A.L., Caldas, C., Foekens, J.A., Martin, S., Reis-Filho, J.S., Richardson, A.L., Sotiriou, C., Stunnenberg, H.G., Thoms, G., van de Vijver, M., van't Veer, L., Calvo, F., Birnbaum, D., Blanche, H., Boucher, P., Boyault, S., Chabannon, C., Gut, I., Masson-Jacquemier, J.D., Lathrop, M., Pauporte, I., Pivot, X., Vincent-Salomon, A., Tabone, E., Theillet, C., Thomas, G., Tost, J., Treilleux, I., Calvo, F., Bioulac-Sage, P., Clement, B., Decaens, T., Degos, F., Franco, D., Gut, I., Gut, M., Heath, S., Lathrop, M., Samuel, D., Thomas, G., Zucman-Rossi, J., Lichter, P., Eils, R., Brors, B., Korbel, J.O., Korshunov, A., Landgraf, P., Lehrach, H., Pfister, S., Radlwimmer, B., Reifenberger, G., Taylor, M.D., von Kalle, C., Majumder, P.P., Sarin, R., Rao, T.S., Bhan, M.K., Scarpa, A., Pederzoli, P., Lawlor, R.A., Delledonne, M., Bardelli, A., Biankin, A.V., Grimmond, S.M., Gress, T., Klimstra, D., Zamboni, G., Shibata, T., Nakamura, Y., Nakagawa, H., Kusada, J., Tsunoda, T., Miyano, S., Aburatani, H., Kato, K., Fujimoto, A., Yoshida, T., Campo, E., Lopez-Otin, C., Estivill, X., Guigo, R., de Sanjose, S., Piris, M.A., Montserrat, E., Gonzalez-Diaz, M., Puente, X.S., Jares, P., Valencia, A., Himmelbauer, H., Quesada, V., Bea, S., Stratton, M.R., Futreal, P.A., Campbell, P.J., Vincent-Salomon, A., Richardson, A.L., Reis-Filho, J.S., 
van de Vijver, M., Thomas, G., Masson-Jacquemier, J.D., Aparicio, S., Borg, A., Borresen-Dale, A.L., Caldas, C., Foekens, J.A., Stunnenberg, H.G., van't Veer, L., Easton, D.F., Spellman, P.T., Martin, S., Barker, A.D., Chin, L., Collins, F.S., Compton, C.C., Ferguson, M.L., Gerhard, D.S., Getz, G., Gunter, C., Guttmacher, A., Guyer, M., Hayes, D.N., Lander, E.S., Ozenberger, B., Penny, R., Peterson, J., Sander, C., Shaw, K.M., Speed, T.P., Spellman, P.T., Vockley, J.G., Wheeler, D.A., Wilson, R.K., Hudson, T.J., Chin, L., Knoppers, B.M., Lander, E.S., Lichter, P., Stein, L.D., Stratton, M.R., Anderson, W., Barker, A.D., Bell, C., Bobrow, M., Burke, W., Collins, F.S., Compton, C.C., DePinho, R.A., Easton, D.F., Futreal, P.A., Gerhard, D.S., Green, A.R., Guyer, M., Hamilton, S.R., Hubbard, T.J., Kallioniemi, O.P., Kennedy, K.L., Ley, T.J., Liu, E.T., Lu, Y., Majumder, P., Marra, M., Ozenberger, B., Peterson, J., Schafer, A.J., Spellman, P.T., Stunnenberg, H.G., Wainwright, B.J., Wilson, R.K. \& Yang, H. (2010) International network of cancer genome projects. Nature, 464: 993-998.

Ledford, H. (2010) Big science: The cancer genome challenge. Nature, 464: 972974.

Lettre, G. (2013) The Search for Genetic Modifiers of Disease Severity in the betaHemoglobinopathies. Cold Spring Harbor perspectives in medicine: doi: 10.1101/cshperspect.a015032.

Lo, Y.M. \& Chiu, R.W. (2010) Noninvasive approaches to prenatal diagnosis of hemoglobinopathies using fetal DNA in maternal plasma. Hematology/Oncology Clinics of North America, 24: 1179-1186.

Masuda, T., Wang, X., Maeda, M., Canver, M.C., Sher, F., Funnell, A.P., Fisher, C., Suciu, M., Martyn, G.E., Norton, L.J., Zhu, C., Kurita, R., Nakamura, Y., Xu, J., Higgs, D.R., Crossley, M., Bauer, D.E., Orkin, S.H., Kharchenko, P.V. \& Maeda, T. (2016) Transcription factors LRF and BCL11A independently repress expression of fetal hemoglobin. Science, 351: 285-289. 
Nienhuis, A.W. \& Persons, D.A. (2013) Development of gene therapy for thalassemia. Cold Spring Harbor perspectives in medicine: doi: 10.1101/cshperspect.a011833.

Orkin, S.H. \& Reilly, P. (2016) MEDICINE. Paying for future success in gene therapy. Science, 352: 1059-1061.

Park, J.Y., Kricka, L.J. \& Fortina, P. (2013) Next-generation sequencing in the clinic. Nat Biotechnol, 31: 990-992.

Provan, D. \& Gribben, J.G. (2010) Molecular Hematology. Oxford, UK, WileyBlackwell. 3rd. Edn.

Roberts, D.J. \& Weatherall, D.J. (2016) Eds. Global Hematology. Hematol Oncol Clin North Am, 30: xiii-xiv.

Royal Society (2005) Personalised Medicine: hope and realities. https://royalsociety.org/topics-policy/publications/2005/personalised-medicines/.

Royal Society (2015) Recent developments in personalised medicine. https://royalsociety.org/topics-policy/publications/2015/personalised-medicine/

Shape of Training. Securing the future of excellent patient care. http://www.shapeoftraining.co.uk/static/documents/content/Shape of training FINAL Report.pdf 53977887.pdf

Simon, R. \& Roychowdhury, S. (2013) Implementing personalized cancer genomics in clinical trials. Nat Rev Drug Discov, 12: 358-369.

Specialty Training Curriculum; Joint Royal Colleges of Physicians Training Board. https://www.jrcptb.org.uk/sites/default/files/2010\%20Haematology\%20(amend ment\%202012).pdf

Van Keuren-Jensen, K., Keats, J.J. \& Craig, D.W. (2014) Bringing RNA-seq closer to the clinic. Nat Biotechnol, 32: 884-885.

Weatherall, D.J. (2001) Phenotype-genotype relationships in monogenic disease: lessons from the thalassaemias. Nature Reviews Genetics, 2: 245-255.

Weatherall, D.J. (2010) Thalassemia as a global health problem: recent progress towards its control in the developing countries. Ann N Y Acad Sci, 1202: 17-23. 
Weatherall, D.J., Brock, D. \& Chee, H.-L. (2002) Genomics and World Health. Geneva, World Health Organization.

Wintrobe, M.M. (1980) Editor. Blood pure and elequent. New York, McGraw-Hill Book Company. 
Table 1

\begin{tabular}{|c|c|c|}
\hline Scientist & Discovery & Value to Clinical Haematology \\
\hline $\begin{array}{l}\text { Van Leeuwenhoek } \\
(1632-1723)\end{array}$ & $\begin{array}{l}\text { Microscopy } \\
\text { The Red Cell }\end{array}$ & Diagnostic haematology \\
\hline $\begin{array}{l}\text { William Hewson } \\
(1739-1774)\end{array}$ & Blood coagulation & Disorders of blood coagulation \\
\hline $\begin{array}{l}\text { Karl Landsteiner } \\
(1868-1943)\end{array}$ & Blood groups & Blood transfusion \\
\hline $\begin{array}{l}\text { Paul Ehrlich } \\
\text { (1854-1915) }\end{array}$ & $\begin{array}{l}\text { Staining and morphology of blood } \\
\text { cells }\end{array}$ & Diagnostic haematology \\
\hline $\begin{array}{l}\text { George Whipple } \\
(1878-1976)\end{array}$ & \multirow{3}{*}{$\begin{array}{l}\text { Dietetic mechanisms of blood } \\
\text { formation }\end{array}$} & \multirow{3}{*}{$\begin{array}{l}\text { Iron deficiency anaemia } \\
\text { Pernicious anaemia }\end{array}$} \\
\hline $\begin{array}{l}\text { George Minot } \\
(1885-1950)\end{array}$ & & \\
\hline $\begin{array}{l}\text { William Castle } \\
(1867-1962)\end{array}$ & & \\
\hline $\begin{array}{l}\text { César Milstein } \\
(1927-1981)\end{array}$ & \multirow{2}{*}{ Monoclonal antibodies } & Diagnostic haematology \\
\hline $\begin{array}{l}\text { Georges Köhler } \\
(1946-1995)\end{array}$ & & $\begin{array}{l}\text { Management of malignant blood } \\
\text { diseases }\end{array}$ \\
\hline $\begin{array}{l}\text { Frederick Sanger } \\
(1918-2013)\end{array}$ & Method for DNA sequencing & $\begin{array}{l}\text { Essential to every aspect of } \\
\text { molecular haematology }\end{array}$ \\
\hline $\begin{array}{l}\text { Linus Pauling } \\
\text { (1901-1994) }\end{array}$ & \multirow{3}{*}{$\begin{array}{l}\text { The structure and function of } \\
\text { haemoglobin and the first } \\
\text { description of an inherited } \\
\text { disorder of haemoglobin at the } \\
\text { molecular level }\end{array}$} & \multirow{3}{*}{$\begin{array}{l}\text { The era of molecular } \\
\text { haematology, diagnosis and } \\
\text { control of inherited blood } \\
\text { disease. } \\
\text { The classification, diagnosis and } \\
\text { management of malignant blood } \\
\text { disease }\end{array}$} \\
\hline $\begin{array}{l}\text { Max Perutz } \\
(1914-2002)\end{array}$ & & \\
\hline $\begin{array}{l}\text { Vernon Ingram } \\
(1924-2006)\end{array}$ & & \\
\hline
\end{tabular}


Table 2

\begin{tabular}{|c|c|c|c|c|}
\hline Genes & Pathways & Aberration & Diseases & $\begin{array}{l}\text { Putative or proven } \\
\text { drugs }\end{array}$ \\
\hline $\begin{array}{l}\text { JAK1, JAK2, JAK3, } \\
\text { STAT1, STAT3 }\end{array}$ & JAK-STAT & $\begin{array}{l}\text { Mutation } \\
\text { Rearrangement }\end{array}$ & $\begin{array}{l}\text { Leukaemia } \\
\text { Lymphoma }\end{array}$ & $\begin{array}{l}\text { JAK-STAT inhibitors } \\
\text { STAT Decoys }\end{array}$ \\
\hline $\begin{array}{l}\text { Erythropoietin receptor } \\
(E P O R)\end{array}$ & JAK-STAT & Rearrangement & Leukaemia & JAK-STAT inhibitors \\
\hline $\begin{array}{l}\text { Interleukin-7 receptor } \\
(I L-7 R)\end{array}$ & JAK-STAT & Mutation & Leukaemia & JAK-STAT inhibitors \\
\hline$A B L-1$ & $A B L$ & Rearrangement & Leukaemia & ABL inhibitors \\
\hline FLT-3 & FLT3 & Mutation or deletion & Leukaemia & FLT3 inhibitors \\
\hline $\begin{array}{l}\text { Fibroblast } \\
\text { Growth Factor } 1 \text { Receptor } \\
\text { FGFR1, FGFR2, FGFR3, } \\
\text { FGFR4 }\end{array}$ & FGFR & $\begin{array}{l}\text { Mutation } \\
\text { Amplification } \\
\text { Rearrangement }\end{array}$ & Myeloma & $\begin{array}{l}\text { FGFR inhibitors } \\
\text { FGFR antibodies }\end{array}$ \\
\hline
\end{tabular}


Table 3

Haematology Specialty Syllabus

H 1 Introduction to Laboratory Haematology.

H 2 Laboratory Haematology

H 3 Anaemia.

H 4 Acute Leukaemia

H 5 Chronic Leukaemia

H 6 Myeloma and other Plasma Cell Dyscrasias

H 7 Lymphoma

H 8 Congenital Coagulation Disorders

H 9 Thrombosis

$\mathrm{H} 10$ Anticoagulation

H 11 Acquired Bleeding Disorders

H 12 Platelet disorders

H 13 Haemoglobinopathies

H 14 Bone marrow failure syndromes

H 15 Myeloproliferative disorders

H 16 Haematology Relating to Other Medical Specialties

H 17 Generic Competencies in Haematology

H 18 Blood Transfusion

H 19 Paediatric Haematology 
Figure 1

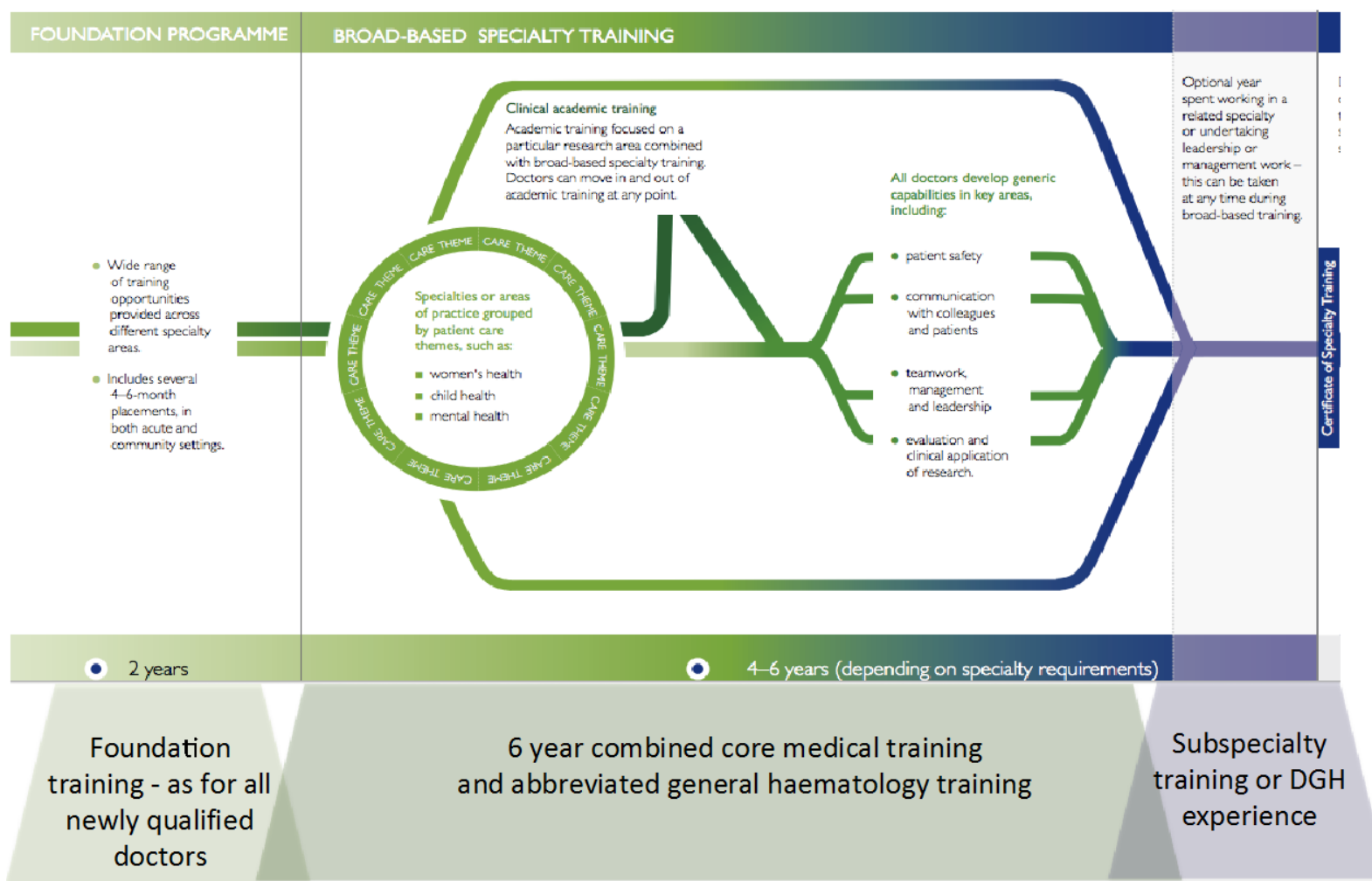

